\title{
CHALLENGES AND CURRENT TRENDS ON THE PROCESS OF RECOGNITION AND ENFORCEMENT OF FOREIGN ARBITRAL AWARDS IN REPUBLIC OF TURKEY
}

\author{
Ulvi Ocaqli \\ Postgraduate student, People's Friendship University of Russia, uocaqli@gmail.com
}

\begin{abstract}
Declaration of republican system by of Mustafa Kemal Ataturk led to new changings not only in political frame but also judicial reforms likewise new constitution, administrative bodies and international cooperation with global powers. The main principle of sovereignty which are established as a fundamental base for M.K.Ataturk republicans continued to operate in the modern era of Turkish judicial system as well. This paper initiates to analyze the one of pivotal principles on grounds recognition and enforcement of foreign arbitral awards namely "public order" principle from the point of view being barrier or instrument in favor or against of Turkish republic and counterparts local or foreign investors. Turkey is mesmerizing place for foreign investors locating between two continents and as a transit country, taking into account lack of natural resources like oil and gas.
\end{abstract}

Keywords: arbitration agreement, arbitration awards, damages, civil law, process

\section{INTRODUCTION}

Republic of Turkey is one of prior problem solver state with its effect to not only the neighbor countries but also over border states which are actively operating the trade transactions and operations through the heart of Europe and Asia. It is not shocking factor that, the companies which are directing and stimulates the global market settles the headquarters in Turkey, believing the superiority of Turkish jurisdiction.

Analyzing the current situation on public order principle is extremely important due to comprehend the level of capability of Turkish republic from the point of view of recognition and enforcement of foreign arbitral awards. On this point, we will go to deep through the ways of recognition and enforcement, grounds of refusal of foreign arbitral awards.

There are number of legal bases of recognition and enforcement of foreign awards likewise Constitution of Turkish Republic and International Private and Procedure Law № 5718 which are mainly regulate the procedural aspects of theme. As all the Republican states, Turkey also uses main legal tool for controlling public order via Constitution, Nevertheless Turkish jurisdiction has its own impact from the side of local legal tools like Constitution and IPPL but Turkish Republic is pivotal contributor on international legal tools as United Nations Convention on Recognition and Enforcement of Foreign Arbitral awards in 1958.

Taking into account the principle of reservation, it is notable fact that Turkey is counterpart of stipulated normative act in case of being signature opponent party. It means that Turkish jurisdictions allow to recognize and enforce the foreign arbitral awards from the states which are parties of New York Convention. 
Referring to the New York Convention, recognition differs from enforcement as a legal concept. Recognition demonstrates itself the gaining legal mass from the point of legality in the territory of Turkish Republic.

Enforcement is legal procedure which is complied with the rule of law principle after recognition. Summarizing the procedure of recognition and enforcement of foreign arbitral awards is gaining legal binding after judge supremacy which is following the decision of court.

Here starts the procedure of courts power to the recognition and enforcement. Courts decision is very important to decide the form of recognition and enforcement the foreign arbitral awards. It is very important to analyze the trends the recognition and enforcement of awards which are rendered outside of Republic of Turkey.

There are number of grounds for recognition and refusal grounds which is found logic end at the $V$ th article of New York Convention of Recognition and Enforcement of Foreign Arbitral awards.

On the other hand, Turkish domestic acts like International Private and Procedural Law № 5718 also regulates the recognition and enforcement part of foreign rendered awards. The main and prior difference between New York Convention and IPPL is defining the understandings between recognition and enforcement of foreign arbitral awards. International Private and Procedural law is limitedly comprehending the definitions recognitions and enforcement which is telling that enumerated definitions are not separately accepted.

The applicable law is also handled in all the legal normative acts in the example of IPPL and New York Convention. International document nominates Turkish Republic as a patronage state on implementation of applicable law, so far Turkish law is key player on decision making way of judicial body.

\section{ACKNOWLEDGEMENT}

This work was financially supported by the Grant of the President of the Russian Federation №. HШ-26682020.6 "National-Cultural and Digital Trends in the Socio-Economic, Political and Legal Development of the Russian Federation in the 21st Century."

\section{RESULTS}

Bearing in mind that Republic of Turkey is key player on the road of main trade transactions among European and Asian companies which are shaping global market, so there are still need to formulate the comprehension of public order principle which is the main barrier to recognize and enforce foreign rendered awards. Here it is very important to define the meaning of the principle of public order that led to put an end stipulated procedure. It should be noted that public order principle is mainly regulated with public policy as well. Deeply analyzing the relations between state policy and public order, there are so many connective factor that making recognition and enforcement procedure dependent from enumerated policy.

\section{REFERENCE LIST}

1. A J van den Berg, The New York Arbitration Convention of 1958 (Kluwer Law International, 1981), pp. 267, 268

2. A J van den Berg, The New York Arbitration Convention of 1958 (Kluwer Law International, 1981), pp. 314, 315 with reference to the English and French texts of the Convention

3. Cruz City 1 Mauritius Holdings v. Unitech Limited, 11 April 2017, EX.P.132/2014 \& EA(OS) Nos. 316/2015, 1058/2015, 151/2016, 670/2016

4. Cruz City 1 Mauritius Holdings v. Unitech Limited, 11 April 2017, EX.P.132/2014 \& EA(OS) Nos. 316/2015, 1058/2015, 151/2016, 670/2016

Svenska Petroleum Exploration AB v. Government of Republic of Lithuania and AB Geonafta [2006] EWCA Civ. 1529 at para. 117

5. P Stothard, A Biscarro, 'Public policy as bar to enforcement', International Arbitration Report (Issue 10, 
May 2018), pp. 23, 24

6. Hilmarton v. Omnium (Court of Cassation, first civil chamber, Case No. 92-15.137 (23 March 1994)), in which the French Court of Cassation permitted enforcement of an arbitral award that has been set aside in Switzerland. See further S Petit, B Grant 'Awards set aside or annulled at the seat', International Arbitration Report (Issue 10, May 2018), pp. 20 to 22

7. Turkish, Indonesian, Chinese and Russian cases in Born, International Commercial Arbitration (2nd edn, Kluwer Law International 2014) p. 3716 to 3718. 